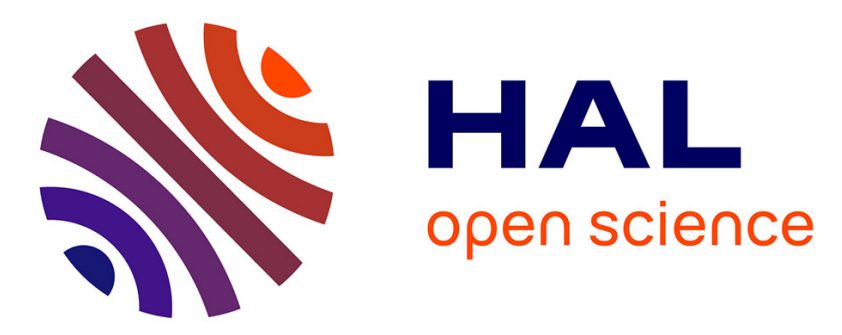

\title{
Using grassed strips to limite pesticide transfer to surface water: a review
}

Jean-Guillaume Lacas, Marc Voltz, Véronique Gouy, Nadia Carluer, J.J. Gril

\section{To cite this version:}

Jean-Guillaume Lacas, Marc Voltz, Véronique Gouy, Nadia Carluer, J.J. Gril. Using grassed strips to limite pesticide transfer to surface water: a review. Agronomy for Sustainable Development, 2005, 25, pp.253-266. 10.1051/agro:2005001 . hal-02587115

\section{HAL Id: hal-02587115 https://hal.inrae.fr/hal-02587115}

Submitted on 31 May 2020

HAL is a multi-disciplinary open access archive for the deposit and dissemination of scientific research documents, whether they are published or not. The documents may come from teaching and research institutions in France or abroad, or from public or private research centers.
L'archive ouverte pluridisciplinaire HAL, est destinée au dépôt et à la diffusion de documents scientifiques de niveau recherche, publiés ou non, émanant des établissements d'enseignement et de recherche français ou étrangers, des laboratoires publics ou privés.

$$
\text { Copyright }
$$




\title{
Using grassed strips to limit pesticide transfer to surface water: a review
}

\author{
Jean-Guillaume LACAS ${ }^{\mathrm{a}, \mathrm{b} *}$, Marc VOLTZ ${ }^{\mathrm{c}}$, Véronique GOUYa, Nadia CARLUER ${ }^{\mathrm{a}}$, Jean-Joël GRIL ${ }^{\mathrm{a}}$ \\ ${ }^{a}$ CEMAGREF, UR Qualité des Eaux et Prévention des Pollutions, 3 bis quai Chauveau, 69336 Lyon, France \\ ${ }^{\mathrm{b}}$ ENGEES, 1 quai Koch, BP 1039F, 67070 Strasbourg, France \\ ${ }^{\mathrm{c}}$ INRA, UMR L.I.S.A.H., 2 place Viala, 34060 Montpellier, France
}

(Accepted 11 January 2005)

\begin{abstract}
Grassed buffer strips are one way to reduce pesticide transfer by surface runoff from farmed fields to streams. Numerous experimental studies have demonstrated that this type of development is very effective in various conditions. The results are nevertheless very variable. This variability is partially explained by the multiplicity of processes and contributive factors and by the fact that the latter are dynamic in nature and site-specific. Several results also show that the intercepted products are not systematically immobilized within the strip but can move in the subsurface, thus affecting the overall effectiveness of the system. As a consequence of this complexity, the present guidelines for the sizing and siting of grassed strips are still only qualitative or are the result of empirical approaches. The present review analyses the available results and defines needs for further research. This concerns several basic processes determining the pesticide interception by grassed strips and numerical models necessary to integrate the complexity of interacting processes and formulate reliable managing guidelines.
\end{abstract}

buffer zone / grassed strip / pesticides / best management practices / nonpoint source pollution / modeling

\section{INTRODUCTION}

Despite the implementation of new regulatory provisions and the progressive introduction of farming practices that restrict the use of the most mobile pesticides, such products are still frequently found in surface waters at concentrations above the maximum level permitted by the European Directive on Drinking Water (98/83/EC). The use of grassed strips in the prevention of nonpoint source pollution of surface water has been the subject of numerous studies over recent decades. Indeed, surface runoff coming from farmed fields is a major source of contamination of surface water. Grassed strips, acting like a buffer zone, can be an effective solution to reduce this type of transfer between the farmed field and the hydrologic reservoirs.

The first experimental results concerned the ability of grassed strips to intercept flows of sediments and nutrients transported by runoff. Two major scientific reviews should be mentioned: one discusses the retention of nitrogen, phosphorus and sediments by grassed strips following the various transport processes (surface runoff, subsurface drainage, and soluble or adsorbed to particles) (Muscutt et al., 1993), and the other analyzes the contradictory results published about nutrient retention on the plot scale and the catchment scale, in order to underline the importance of appropriately locating the buffer zone in accordance with the local buffer physical characteristics or the type of pollutant concerned (Norris, 1993). The results acquired on the ability of grassed strips to capture pesticides in surface runoff are more recent, although a few isolated studies can be found before 1990 (Asmussen et al., 1977; Rohde et al., 1980). Indeed, the literature has grown considerably over the last ten years, and has been particularly concerned with the limitation of water pollution by herbicides. As well as evaluating the effectiveness of grassed strips in retaining these products, these studies have been designed to provide a better understanding of the processes and factors involved in pesticide retention by the strips. The ultimate aim was to determine rules for sizing and locating the strips in order to optimize their efficiency for limiting surface water pollution at the outlet of fields and watersheds. As far as we know, only one review has been published until now about pesticide retention by grassed strips (USDA-NRCS, 2000). Its main aim was practical; namely, to help American engineers assisting farmers and landowners installing conservation buffers. This report deals with different types of buffers, lists the results published about the potential of buffers to limit pesticide transport by surface runoff, and gives technical and economical considerations for buffer locating, sizing and maintenance. Finally, the review of Dosskey (2001) should also be mentioned even if only some of the presented results concern pesticides, because it is a recent and

\footnotetext{
* Corresponding author: lacas@lyon.cemagref.fr
} 
major review. All the environmental functions of buffers (surface runoff reduction and filtration, groundwater filtration, bank stabilization and stream water filtration) were evaluated, and information gaps were identified.

The main aims of the present review are to define which mechanisms involved in the epuration potential of grassed strips are now well understood and which need further research, in the specific case of pesticide transport by surface runoff. In this respect, four specific questions are addressed hereafter:

(1) What are the main sources of variation of the effectiveness of grassed strips for intercepting pesticides in surface runoff?

(2) What is the fate of the compounds intercepted by a grassed strip?

(3) What are the existing modeling approaches to the simulation of grassed strips and what are their limits?

(4) What are the current recommendations applied for dimensioning and locating a grassed strip in a watershed and how are they consistent with our current state of knowledge?

\section{VARIATION IN INTERCEPTION PERFORMANCE OF GRASSED STRIPS}

Table I shows the latest works on pesticide retention by grassed strips, complementing the previously published literature review (USDA-NRCS, 2000). The presented results confirm that grassed strips can be very efficient at dissipating flows of pesticides present in the surface runoff. However, they also show a large variability of the observed efficiencies, as has already been emphasized elsewhere (Dosskey, 2001, 2002). Interpreting this variability is a complex matter.

This is primarily due to large differences in the experimental protocols, as can be seen in Table I. A first source of differences is related to the kind of experiment, in natural or simulated flow conditions. Experiments conducted under natural conditions reproduce the configuration of a grassed strip adjacent to a cultivated plot subject to rainfall. Measurements are made continuously for a long time, i.e. for a wide range of hydrologic conditions on the same plot. In contrast, experiments based on rainfall and/or runoff simulations have several restrictive features. The simulated hyetographs and/or hydrographs usually consist only of a single runoff event with constant and timelimited flow. The dimensions of the simulators are small, resulting in large grassed surface / treated surface ratios. The grassed part is usually not watered (except in combined runoff+rainfall systems) so dilution processes and increase in transport capacity due to rain falling directly on the strip are not taken into account. The strip is usually "dry" when the simulated runoff starts. In runoff simulations, the flow has a null velocity when it enters the strip; its concentration in pesticide is kept constant throughout the runoff event. These differences between natural and simulated flow conditions raise doubts about the representativeness of the results obtained with simulators and may explain in part the variable observed efficiencies of grassed strips.

A second source of variability is the large variation of many experimental parameters (e.g. the treated area vs. grassed area ratio or incoming flow rate, molecule type, grassed length, soil

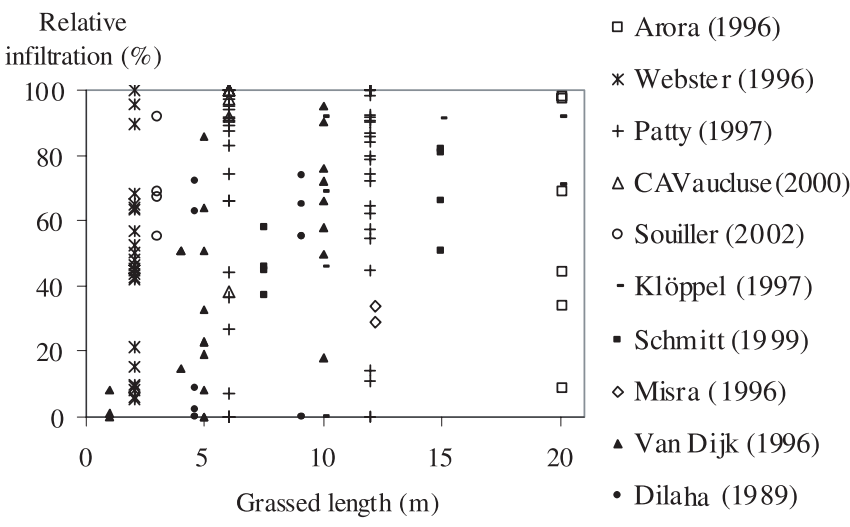

Figure 1. Relative infiltration capacities determined on the event scale by several authors, for different grassed lengths: illustration of the results' dispersion.

type or initial soil moisture) between the experiments, making it difficult to compare the results. Several parameters often vary simultaneously and in turn it is difficult to detect which parameter may explain the exact origin of the observed differences in efficiency among several experiments. This is reinforced by the fact that in many papers key parameters, such as the soil water status at the time of the event or the soil hydrodynamic properties, are not indicated, or worse, were not measured.

A last source is the difference in the way the grassed strip efficiencies are expressed: in terms of pesticide mass, in terms of mean concentration or flux, or in terms of instantaneous concentration. Furthermore, the elements needed to harmonize these results are not always provided.

Finally, comparing results stemming from different experiments and different authors appears to be quite hazardous. To illustrate this, Figure 1 compares the infiltration capacities of grassed strips as observed by several authors. The dispersion of results is tremendous and cannot be related to variations in the length of the strip, which is thought of as a main parameter of grassed strips' efficiency.

In sum, the effectiveness variability suggests that a wide range of physical and biochemical processes are involved in the functioning of grassed strips and that their relative importance can vary from one situation to another as a function of numerous parameters. It is therefore necessary to move beyond simple recognition of the effectiveness of a grassed strip and to examine its behavior from a mechanistic point of view, with the aim of explaining the variability of the experimental results. To this end, we review below the factors that were shown in the literature to be involved in the interception capacity of a strip.

\subsection{Mechanisms of interception}

Overall, four main processes are thought to be responsible for the interception properties of a grassed strip (see Fig. 2).

\subsubsection{Infiltration}

Many authors have shown that the main advantage of a strip lies in its high infiltration capacity (Muscutt et al., 1993; Patty, 
Table I. Published results about the interception effectiveness of grassed strips.

\begin{tabular}{|c|c|c|c|c|c|c|c|c|}
\hline \multirow[t]{3}{*}{ Reference } & \multirow{3}{*}{$\begin{array}{l}\text { Experimental } \\
\text { method }\end{array}$} & \multicolumn{2}{|c|}{ Dimensions } & \multirow{3}{*}{$\begin{array}{l}\text { Parameter } \\
\text { tested }\end{array}$} & \multirow{3}{*}{$\begin{array}{c}\text { Data } \\
\text { Measurement type } \\
\text { Result type (repet.) }\end{array}$} & \multirow{2}{*}{\multicolumn{3}{|c|}{$\begin{array}{l}\text { Interception effectiveness } \\
\qquad(\%)\end{array}$}} \\
\hline & & \multirow{2}{*}{$\begin{array}{l}\text { Length } \\
\text { (m) }\end{array}$} & \multirow{2}{*}{$\begin{array}{c}\text { Surface } \\
\text { ratio (\%) }\end{array}$} & & & & & \\
\hline & & & & & & Pollutant & Mass & Conc. \\
\hline \multirow[t]{4}{*}{ Arora et al. (1996) } & Natural rainfall & 20 & 5 & Molecule type & Instantaneous & Water & $9-98$ & \\
\hline & & & & & Total per event (6) & Atrazin tot. & $13-100$ & \\
\hline & & & & & & Metolachlor tot. & $22-100$ & \\
\hline & & & & & & Cyanazin tot. & $15-100$ & \\
\hline \multirow{3}{*}{$\begin{array}{l}\text { Webster and } \\
\text { Shaw (1996) }\end{array}$} & Natural rainfall & 2 & 18 & Molecule type & Total per event (24) & Water & $0-65$ & \\
\hline & & & & Runoff load & year averaged (3) & Metolachlor dis. & $13-88$ & \\
\hline & & & & & & Métribuzin dis. & $22-89$ & \\
\hline \multirow[t]{5}{*}{ Patty et al. (1997) } & Natural rainfall & 6,12 & $12-36$ & Molecule type & Total per event (32) & Water & $43-100$ & \\
\hline & & 18 & & Grassed length & year averaged (2) & Isoproturon dis. & $99-100$ & \\
\hline & & & & & & Diflufenican dis. & $97-100$ & \\
\hline & & & & & & Atrazin dis. & $44-100$ & \\
\hline & & & & & & Lindane dis. & $72-100$ & \\
\hline Lecomte (1999) & Natural rainfall & 3,6 & 5,10 & Grassed length & Instantaneous & Water & $7-100$ & \\
\hline & & & & Length partition & Total per event (55) & Isoproturon tot. & $76-97$ & \\
\hline & & & & Source area & year averaged (2) & Diflufenican tot. & $60-95$ & \\
\hline & & & & Molecule type & & & & \\
\hline & & & & Solid transport & & & & \\
\hline Lowrance et al. & Natural rainfall & 8 & & Molecule type & Total per event & Atrazin tot. & $37-86$ & $0-68$ \\
\hline (1997) & & & & & year averaged ( 3 ) & Alachlor tot. & $50-94$ & $0-75$ \\
\hline Tingle et al. (1998) & Natural rainfall & $0.5-4$ & $2-18$ & Molecule type & Total over $2 \mathrm{~d}$ and $84 \mathrm{~d}$ & Water & $47-69$ & \\
\hline & & & & Grassed length & after application & Metolachlor dis. & $48-68$ & $48-69$ \\
\hline & & & & & year averaged (3) & Metribuzin dis. & $48-69$ & $48-68$ \\
\hline Rankins et al. (2001) & Natural rainfall & 0.3 & 1.4 & Molecule type & Instant. conc., total & Water & $49-76$ & \\
\hline & & & & Vegetation & runoff over $127 d$ & Fluometuron dis. & $59-84$ & $32-71$ \\
\hline & & & & & year averaged (3) & Norflurazon dis. & $45-86$ & $35-66$ \\
\hline Vellidis et al. (2002) & Natural rainfall & 8 & 80 & Molecule type & Total per event & Atrazin tot. & $92-97$ & $61-89$ \\
\hline & & & & & year averaged (2) & Alachlor tot. & $91-99$ & $73-95$ \\
\hline & & & & & & Bromide & & $55-73$ \\
\hline & Natural rainfall & $3-6$ & $4-8$ & Molecule type & Total per event (29) & Water & $55-86$ & \\
\hline du Vaucluse $(2000)$ & & & & Grassed length & year averaged (3) & Diuron tot. & $77-88$ & \\
\hline & & & & & & Fosethyl-Al tot. & $37-100$ & \\
\hline & & & & & & Thiodicarb tot. & $14-91$ & \\
\hline Spatz et al. (1997) & Simulated rainfall & $1-15$ & $14-214$ & Soil moisture & Instantaneous & Pendimethalin tot. & $77-100$ & \\
\hline & $60 \mathrm{~mm} / \mathrm{h}$ & & & Grassed length & Total per event (1) & Fenpropimorph tot. & $42-100$ & \\
\hline & $90-180 \mathrm{~min}$ & & & Soil type & & Terbuthylazin tot. & $29-100$ & \\
\hline & & & & Molecule type & & Primicarb tot. & $23-100$ & \\
\hline & & & & & & Isoproturon tot. & $18-100$ & \\
\hline Souiller et al. (2002) & Simulated runoff & 3 & & Flow rate & Instantaneous & Water & $55-92$ & \\
\hline & $117-200 \mathrm{~mm} / \mathrm{h}$ & & & Molecule type & Constant flow (1) & Diflufenican dis. & $61-98$ & $25-70$ \\
\hline & $60-150 \mathrm{~min}$ & & & Seasonality & & Atrazin dis. & $60-95$ & $<10$ \\
\hline & & & & & & Isoproturon dis. & $61-79$ & $<10$ \\
\hline & & & & & & Diuron dis. & $62-81$ & \\
\hline Syversen and & Simulated runoff & $5-7.5$ & & Grassed length & Instantaneous & Glyphosat dis. & & $24-70$ \\
\hline Bechmann (2003) & $38-58 \mathrm{~mm} / \mathrm{h}$ & & & Seasonality & Constant flow (1) & Glyphosat part. & & $10-80$ \\
\hline & $300 \mathrm{~min}$ & & & Molecule type & & Fenpropimorph dis. & & $32-78$ \\
\hline & & & & Solid transport & & Fenpropimorph part. & & $50-95$ \\
\hline & & & & & & Propiconazol dis. & & $61-73$ \\
\hline & & & & & & Propiconazol part. & & $0-70$ \\
\hline Klöppel et al. (1997) & Simulated runoff & $10-20$ & & Grassed length & Total per event (1) & Water & $0-92$ & \\
\hline & $400-2000 / / h$ & & & Flow rate & & Dichlorprop-p & $61-98$ & $14-73$ \\
\hline & Simulated rainfall & & & Molecule type & & Isoproturon & $70-98$ & $10-79$ \\
\hline & $14 \mathrm{~mm} / \mathrm{h}$ & & & Flow dispersion & & Terbuthylazin & $70-98$ & $30-79$ \\
\hline Schmitt et al. (1999) & Simulated runoff & $7.5-15$ & $9-19$ & Grassed length & Total per event (1) & Water & $35-80$ & \\
\hline & $100-200 \mathrm{~mm} / \mathrm{h} ; 25^{\prime}$ & & & Molecule type & & Permethrin tot. & $45-95$ & $5-80$ \\
\hline & Simulated rainfall & & & Vegetation & & Atrazin tot. & $30-90$ & $0-40$ \\
\hline & $50 \mathrm{~mm} / \mathrm{h} ; 30^{\prime}$ & & & & & Alachlor tot. & $40-90$ & $5-65$ \\
\hline Misra et al. (1996) & Simulated runoff & 12 & $3-7$ & Flow rate & Total per event (1) & Water & $29-34$ & \\
\hline & $190-380 \mathrm{~mm} / \mathrm{h} ; 45^{\prime}$ & & & Runoff load & & Atrazin dis. & $26-50$ & $0-7$ \\
\hline & Simulated rainfall & & & & & Metolachlor dis. & $27-47$ & $0-2$ \\
\hline & $64 \mathrm{~mm} / \mathrm{h} ; 60^{\prime}$ & & & & & Cyanazin dis. & $26-47$ & $0-2$ \\
\hline Krutz et al. (2003) & Simulated runoff & 3 & 10 & Molecule type & Total per event (4) & Atrazin & 22 & 9 \\
\hline & 250 mm/h;60' & & & & & diaminoatrazin & 19 & 6 \\
\hline & & & & & & deisopropylatrazin & 19 & 6 \\
\hline & & & & & & desethylatrazin & 19 & 6 \\
\hline & & & & & & hydroxyatrazin & 19 & 6 \\
\hline
\end{tabular}




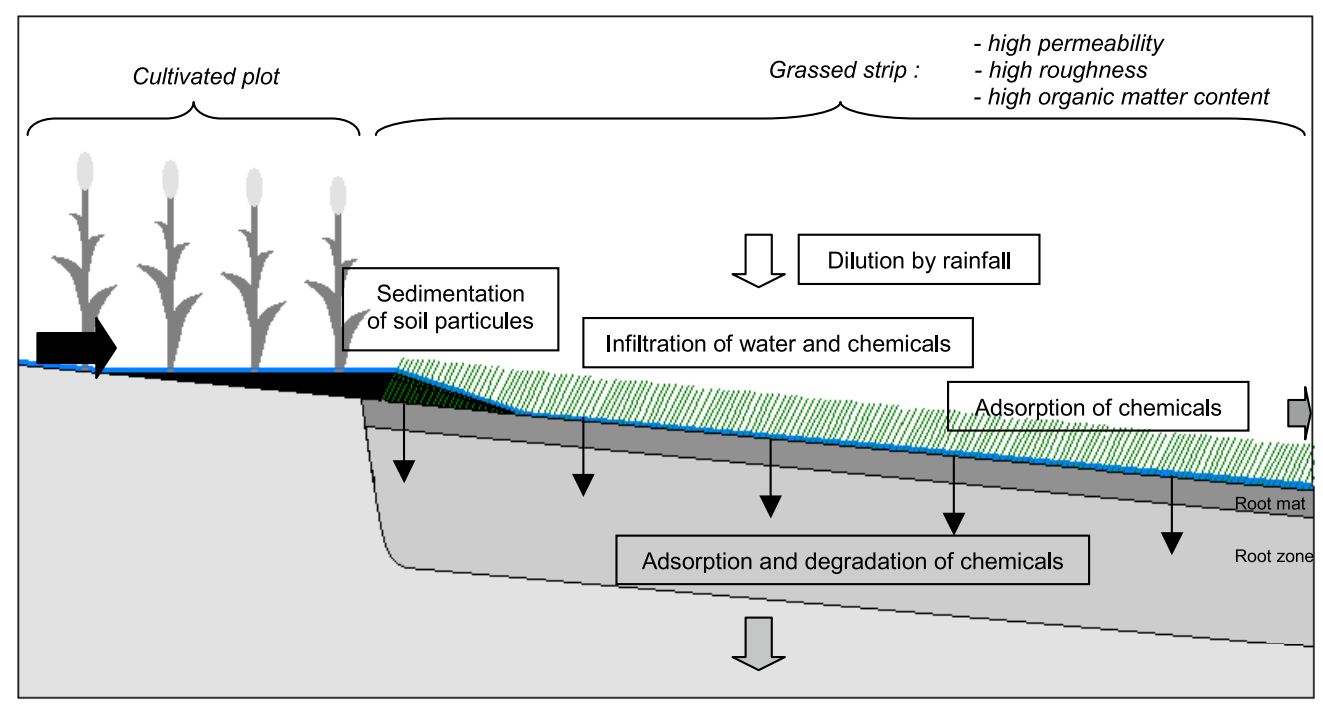

Figure 2. Processes occurring in a grassed strip.

1997; USDA-NRCS, 2000) (see Tab. I for quantitative data). This process primarily acts on the compounds in solution, a part of which infiltrates the soil. However, fine $(<0.45 \mu \mathrm{m})$ particles can also penetrate the soil, carrying with them molecules adsorbed to their surface (Mercier, 1998). Few in situ measurements of the permeability of grassed strips are available: they are all particularly high, ranging, for example, from 2 to $58 \mathrm{~cm} / \mathrm{h}$ for a cover of 7-year-old Perennial ryegrass (Lolium perenne) (Souiller et al., 2002) and from 15 to $33 \mathrm{~cm} / \mathrm{h}$ for the root zone of a 2- to 3-month-old fescue cover (Watanabe and Grismer, 2001). It has been noted that grassing can modify the pore characteristics of the soil surface layer. This can be explained by the structuring effect of the grass rooting system, which is particularly dense, and by the increase in soil organic matter (Benoit et al., 1999; Madrigal et al., 2002), the latter having a stabilizing effect on particle aggregates (Tisdall and Oades, 1982). Macrofaunal activity also plays a role: populations of rodents, moles or earthworms are usually high on grasslands, because of the presence of food, the absence of pesticide treatment and the absence of tillage (Beven and Germann, 1982), and they encourage the formation of rapid flow paths. Observations on soil cylinder samples from grassed strips confirm the presence of roots and worm holes (2-3 $\mathrm{mm}$ in diameter) up to $30 \mathrm{~cm}$ below the surface (Benoit et al., 2000; Pot et al., 2003). However, there are very few quantitative data on the impact of macroporosity of plant or animal origin on infiltration capacity.

\subsubsection{Sedimentation}

This process reduces the flow of suspended particles and thus the flow of pesticides adsorbed to their surface. Laboratory canal experiments have shown that particle retention occurs mainly as a result of sedimentation upstream of the strip, in the area of still water that builds up against the upper boundary of the grassed zone (Dabney et al., 1995; Ghadiri et al., 2001; Meyer et al., 1995), rather than as a result of the filtering effect (in the mechanical sense of the term) of the vegetation itself.
The transport capacity in this still water area is virtually zero, leading to rapid deposit of the suspended particles (Dabney et al., 1995; Jin et al., 2000). However, the deposit formed upstream can be carried inside the strip more or less rapidly (Dillaha et al., 1989). It must also be noted that sediment deposits may lead to a great malfunctioning of the grassed strip in erosive areas. Deposition that occurs upstream of the grassed strip can increase to the point of forming ridges that concentrates the flow in local outlets (Dillaha et al., 1989) or in extreme cases, to the point of sealing the grass roughness, which induces the formation of water pathways with high velocities.

\subsubsection{Dilution}

This operates at the surface of the strip when uncontaminated rainwater falls on the strip and mixes with the contaminated runoff coming from upstream. The dilution factor (rainfall / rainfall+runoff) is usually non-negligible (Lowrance et al., 1997; Schmitt et al., 1999; Vellidis et al., 2002). It is determined by the area of grassed zone / area of treated zone ratio and by the runoff and rainwater volumes. The recorded observations show concentration reductions associated with dilution ranging from 25 to $50 \%$ for an 8-m strip downstream of a 2.5-ha cultivated plot (Lowrance et al., 1997), from 30 to $67 \%$ for an 8-m strip downstream of a 10-m hillslope (Vellidis et al., 2002), and from 15 to $30 \%$ for $7-\mathrm{m}$ and $15-\mathrm{m}$ strips, respectively, receiving the runoff of an 80-m cultivated hillslope (Schmitt et al., 1999). However, we must underline that dilution influences only the concentration of pesticides in overland flow, but does not change the loads of pesticides crossing the grassed strip.

\subsubsection{Adsorption}

This concerns molecules in solution. It occurs on the soil surface, on the aboveground part of the vegetation and on any other plant debris on the surface of the strip. The aboveground part 
of the vegetation and the partially humified plant debris have the highest adsorption capacities (Benoit et al., 1999; Lickfeldt and Branham, 1995), while the soil has a smaller but still significant capacity, higher than for the same soil when cultivated or bare (Benoit et al., 1999, 2000; Madrigal et al., 2002; Mersie et al., 1999; Reungsang et al., 2001; Staddon et al., 2001). This adsorption capacity varies according to the soil organic matter content (Benoit et al., 1999; Reungsang et al., 2001; Staddon et al., 2001). Quantification of the role of adsorption in the effectiveness of grassed strips is quite difficult experimentally: direct measurements of the amount of adsorbed pesticides on the soil and plant materials of the strip are difficult from an analytical point of view since the amounts are small. So, the values are most often estimated indirectly from the difference between pesticide concentrations entering and exiting the strip by overland flow. This makes it necessary to take into account the other processes responsible for the reduction of pesticide concentration in overland flow crossing the strip: namely, dilution by rainfall, but also infiltration. This explains why there are few reliable quantitative results concerning the impact of adsorption on the flows of pesticide conveyed. Nevertheless, it was shown that adsorption is a significant retention mechanism, although there are conflicting reports about the exact value of the process contribution (Arora et al., 1996; Krutz et al., 2003; Misra et al., 1996; Souiller et al., 2002; Spatz et al., 1997).

\subsection{Major properties of grassed strips influencing interception}

\subsubsection{Infiltration}

The infiltration capacity of a strip is controlled by several factors. One is the infiltrating area of the strip, which depends on the dimensions of the system (length and width). The impact of the grassed length on infiltrated volumes has been demonstrated by many authors, who compared outflows from strips of different lengths (C.A.Vaucluse, 2000; Dillaha et al., 1989; Lim et al., 1998; Patty et al., 1997; Schmitt et al., 1999; Spatz et al., 1997; van Dijk et al., 1996). The infiltrating area also depends, however, on the uniformity of the surface flow on the strip. With most grassed strips the effective width of flow is less than the width of the strip. Channelized flow often occurs as a consequence of non-flat topography (Abu-Zreig et al., 2001; Dillaha et al., 1989; Lecomte, 1999) or of concentrated entering flow.

Other factors of control are the soil hydraulic properties, which vary according to the pore structure of the soil surface layer, and to all factors influencing it, namely the soil type, the precedent soil treatments, and the age and nature of the sward, since it has a structuring effect on soil porosity (Benoit et al., 1999, 2000; Reungsang et al., 2001).

A last set of factors is the initial and boundary conditions of the strip. As shown by the infiltration theory (Smith, 2002), the initial soil water status, the presence of an impermeable layer close to the soil surface and the water height of surface flow during the flood event are of importance. Observations on grassed strips confirmed that the infiltration capacity is less when the soil is already close to saturation at the beginning of the runoff event (Arora et al., 1996). Also, the infiltration capacity will tend more or less rapidly towards zero when an imperme- able boundary does exist in the soil profile. Reciprocally, there is no direct evidence whether the variation in hydraulic head is an important factor of variation of observed infiltration capacities, since it is difficult to measure accurately the flow water heights on grassed soils. Several experiments indicated that when the flow rate increases, infiltration increases by a similar amount, e.g. by a factor of 1.7 (Arora et al., 1996; Misra et al., 1996) or 1.5 (Souiller et al., 2002) when runoff doubles. But this effect might also be due to an increase in the infiltrating area, as a high flow rate will overflow the microtopography.

\subsubsection{Sedimentation}

Several studies have shown that the grassed length is not a determining parameter for the retention of suspended matter, even if it favors it (C.A.Vaucluse, 2000; Dillaha et al., 1989; Lim et al., 1998; Schmitt et al., 1999; Spatz et al., 1997; Srivastava et al., 1996; Tingle et al., 1998). This is consistent with in situ observations, already reported above, showing that sedimentation essentially occurs either in the first few decimeters of the strip (Tingle et al., 1998) or upstream of it (Dabney et al., 1995; Ghadiri et al., 2001; Meyer et al., 1995). Experiments using laboratory models indicate that the parameters influencing upstream sedimentation are the size distribution of the suspended particles, the velocity of the flow entering the strip and the height of water built up against the upstream boundary of the strip by a dam effect (Dabney et al., 1995). The mechanical properties of the grass cover, and in particular its density and its resistance to bending (linked to stem diameter), are therefore determining factors (Jin et al., 2000; Meyer et al., 1995). Vegetation density is linked to the grass age so that significant differences are observed between 2-year-old strips and denser 15or 25-year-old strips (Schmitt et al., 1999; van Dijk et al., 1996). Regarding the impact of the size distribution on particle trapping, in situ experiments confirm that the coarsest particles are deposited first (Lee et al., 2000), so that the relative proportion of the finest particules $(<20 \mu \mathrm{m})$ in total solid transport increases between the entry and the exit of a grassed strip (Lecomte, 1999). This is of first importance since pesticide concentration can be ten times higher in this fraction $(<20 \mu \mathrm{m})$ than in coarser ones (Lecomte, 1999): thus, the sedimentation process could have only a reduced impact on the transport of pesticides, even if strongly adsorbed products are concerned.

\subsubsection{Adsorption}

The overall adsorption capacity of the strip is primarily determined by the contact area between flowing water and the soil and vegetation of the strip. It might therefore be correlated with the length of the strip, the effective width of flow and the surface roughness/height of runoff water ratio. However, relevant experimental results about the adsorption process in grassed strips are few in number. They show no clear correlation between the length of the grassed strip and reduction in concentrations by adsorption (Patty, 1997; Tingle et al., 1998). There are contradictory results on the effect of water height (Misra et al., 1996; Souiller et al., 2002) and no results at all concerning the impact of the effective flow width. A plant density effect has, however, been demonstrated: atrazin, alachlor and permethrin concentrations were statistically smaller at the 
outflow of a 25-year-old grassed strip than at that of a (less dense) 2-year-old strip (Schmitt et al., 1999).

The variation of adsorption capacities of grassed strips may also be related to the known factors of the adsorption process of organic compounds; namely, the nature of the adsorbate, that of the adsorbents, the water content of the adsorbent, the quantity of available adsorbate, the presence of other organic molecules or mineral ions, the $\mathrm{pH}$ and the temperature (Calvet et al., 1980). As far as organic pesticides are concerned, laboratory studies have shown that their adsorption is almost proportional to the organic matter content of the substrate (Stoeckel et al., 1997). Studies on grassed strips confirmed it and showed large adsorption capacities due to large organic matter contents (Benoit et al., 1999; Madrigal et al., 2002; Reungsang et al., 2001). The relationship between adsorption and organic matter content is generally represented by the $K_{o c}$ $\left[\mathrm{L}^{3} \cdot \mathrm{M}^{-1}\right]$ coefficient that is derived from the soil/water partition coefficient $K_{d}\left[\mathrm{~L}^{3} \cdot \mathrm{M}^{-1}\right]$ :

$$
K_{d}=\frac{C_{s}}{C_{e q}} ; K_{o c}=\frac{K_{d}}{f_{o c}}
$$

where $C_{s}$ is the adsorbed concentration $\left[\mathrm{M}^{-\mathrm{M}^{-1}}\right], C_{e q}$ the concentration of the product in solution $\left[\mathrm{M}_{\mathrm{L}} \mathrm{L}^{-3}\right]$ and $f_{o c}$ the mass fraction of soil organic carbon [-].

The $K_{o c}$ can be regarded as intrinsic to each compound and varies considerably among the compounds. As a result, the adsorption capacity of a strip also varies very much according to the coumpound of interest (Schmitt et al., 1999; Souiller et al., 2002; Spatz et al., 1997). For instance, the concentration of diflufenican $\left(K_{o c}\right.$ of $\left.1990 \mathrm{~L} / \mathrm{kg}\right)$ in the liquid phase of the surface runoff can be reduced by two-thirds as it passes through a grassed strip, whereas the concentrations of atrazin and isoproturon ( $K_{o c}$ of $38-174 \mathrm{~L} / \mathrm{kg}$ and $80-230 \mathrm{~L} / \mathrm{kg}$, respectively) are not reduced at all (Souiller et al., 2002). The overall retention (infiltration + adsorption) of pendimethalin $\left(K_{o c}\right.$ of $\left.5000 \mathrm{~L} / \mathrm{kg}\right)$ in a grassed strip can be $96 \%$ while only $75 \%$ of isoproturon $\left(K_{O c}\right.$ of $122 \mathrm{~L} / \mathrm{kg}$ ) is retained (Spatz et al., 1997).

It must be underlined that the total organic matter content of the substrate is not the only factor defining the retention of a given compound. Laboratory studies of soil samples taken from grassed strips indicate that the nature of the organic matter, and particularly its degree of mineralization can also have an impact. For example, partially humified organic matter, enriched in constituents such as lignins or cutins were shown to increase adsorption (Benoit et al., 1999). Moreover, in a carbonated and/or calcareous soil, the hydrophobic character of the organic matter declines and hence also the retention of neutral hydrophobic molecules (e.g. isoproturon) or very hydrophobic molecules (e.g. diflufenican) (Madrigal et al., 2002). Another factor determining adsorption is clay content, the second most significant adsorbent of the soil after organic matter. The clay influence is considered to be significant if the clay / organic matter ratio is above 30 (Staddon et al., 2001).

Finally, the adsorption capacity of a grassed strip also depends on kinetics aspects since flow is transient and adsorption is not an instantaneous process. In the case of isoproturon and diflufenican, it was shown that equilibrium between the concentrations of pesticides in the adsorbed phase and in the liquid phase is reached after a delay of 5 minutes to several hours, depending on the substrates (Madrigal et al., 2002; Margoum et al., 2001). In comparison, since flow velocities on a grassed substrate can be estimated to be of the order of about one meter per minute (Gril et al., 1996), contact times are of the order of a few minutes depending on the length of the grassed strip. This means that equilibrium may not be reached for the specific flow conditions in a strip. Although there are too few results on the adsorption kinetics of pesticides to soil to draw any firm conclusions, it is reasonable to assume that adsorption kinetics significantly limit the adsorption on the strips for standard strip lengths and flow rates. This also shows the difficulty of interpreting results obtained under real flow conditions using adsorption coefficients obtained in batch experiments with long contact times, high concentrations and sufficient agitation to ensure optimum contact between the two phases. In turn, it suggests a need for additional studies on pesticide adsorption by grassed strips under realistic flow conditions.

\subsection{Temporal changes in interception effectiveness}

It must be emphasized that the effectiveness of a grassed strip varies over time, according to the dynamic of each process and the factors controlling them. The evolution of the strip must be taken into account to explain the observed variations in the interception effectiveness of water and pesticide overland flows by a grassed system under natural conditions on event, year and long-term scales. Several processes are involved.

First, rainfall regimes and upstream runoff impose variable supply conditions in terms of water flow rate and pesticide concentrations, and in terms of variable initial soil moistures of the strip, both on the event and year scales. Since infiltration, adsorption and sedimentation processes depend on the characteristics of the incoming flux and on the initial conditions, this leads to large variations in the apparent effectiveness of the strip on the event (Arora et al., 1996) and year scales (Arora et al., 1996; Lowrance et al., 1997; Rankins et al., 2001; Tingle et al., 1998).

Second, biological processes such as root development, changes in organic matter content and macrofaunal activity also largely influence the interception capacity of a strip, but mainly on annual or longer timescales. For example, they were shown to lead to changes in soil permeability (Benoit et al., 1999; Beven and Germann, 1982; Reungsang et al., 2001; Souiller et al., 2002) by a modification of the soil poral structure, or to an increase in adsorption capacity by a larger organic matter content (Benoit et al., 1999).

Third, a major factor of evolution is the sedimentation process. It can lead to significant changes in soil permeability, slope and surface roughness which alter the infiltration rates, favor channel flow and in turn decrease the infiltration capacity of the strip (Deletic, 2000; Misra et al., 1994). These effects occur on the event scale as well as on longer scales. In the long term, the negative effects of the sediment deposits can counterbalance the positive effects of biological activity on permeability and adsorption, and may require some management of the strip (levelling, tillage or resowing).

\subsection{Knowledge needs about interception performance}

The main processes and properties of the strips which determine their interception effectiveness are known at least from a 
Table II. Presentation of processes and main parameters controlling the buffer capacity of a grassed strip.

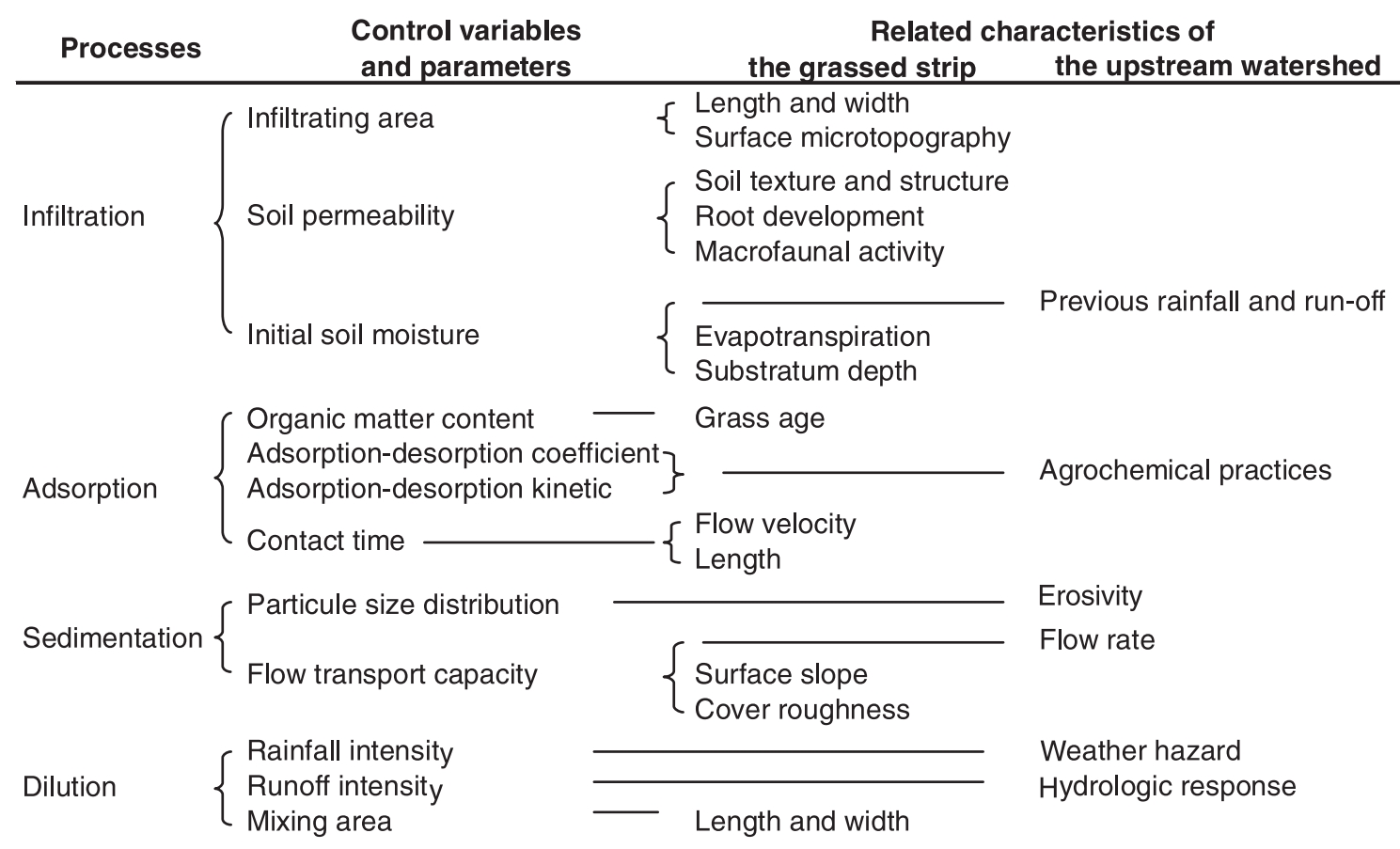

qualitative point of view. Table II summarizes the processes, their control variables or parameters and the strip properties that influence them. However, the prediction of the interception effectiveness of a given strip still seems unattainable with the present state of knowledge. In our opinion, there are two major reasons for this.

The first one stems from the number of interacting processes and strip properties, which is so large that the global functioning of a strip does not seem to be predictable by a simple model and from a few characteristics of the strip (e.g. strip length). Evidence of this is the large variation in observed interception effectiveness, which appears difficult to relate to the variation of the strip properties. Concerning the latter, we must stress that in many papers the observed effectivenesses of grassed strips are published without any proper description of the intrinsic characteristics of the strips, or of the initial and boundary conditions. As a consequence, despite the large number of available experiments, the number of relevant data is small for elucidating the sources of variation of the functioning of grassed strips.

The second reason is that some processes are clearly insufficiently described from a quantitative point of view. Among them the main points are the channeling of surface flow within a strip, the contribution of preferential flows to the infiltration process, the fate of fine solid particles in relation to the sedimentation and infiltration processes, the adsorption process on plant and soil materials (and its variation according to the flow conditions and the type of organic substrate), and the temporal changes in strip characteristics due to biological activity and/ or the sedimentation process.

\section{FATE OF PESTICIDES INTERCEPTED BY A GRASSED SYSTEM}

Little work has been done on what becomes of the products intercepted by a buffer strip. This issue is, however, important because grassed strips are often established close to streams and, hence, are potentially close to surface- and groundwaters. The following questions arise: are the products adsorbed to the solid soil matrix? What is their degradation rate after adsorption? What is the risk that the products will be transferred to depth, both through direct percolation of the contaminated runoff water via macropore-type preferential flow paths and through the leaching of molecules previously adsorbed to the soil matrix of the grassed strip? Can lateral subsurface transfer occur? Are such transfers sufficiently large to significantly affect the actual effectiveness of a grassed system? Is there a large risk of contamination if the grassed strip is above a shallow water table or established on a river bank (the case of riparian strips)?

\subsection{Degradation of infiltrated products}

The degradation process concerns the infiltrated compounds that remain in the soil after infiltration either in the adsorbed 
phase or in the liquid phase. Degradation decomposes the parent molecule into by-products, that can have an even higher reactivity with the soil components than the parent material. Such is the case with isoproturon (Benoit et al., 1999, 2000), metolachlor (Staddon et al., 2001) and atrazin (Mersie et al., 1999), molecules that have a moderate $K_{o c}$ but are rapidly decomposed and have metabolites that are adsorbed to a much greater extent than the parent molecule. It has generally been observed that grassed strips have a high degradation potential because of their high total and readily available organic carbon content. Fungi and bacteria populations and enzyme activity are up to 4 times higher within a grassed soil than in bare soil (Staddon et al., 2001). This explains the faster degradation kinetics noted in grassed soils than in tilled soils (Benoit et al., 2000; Mersie et al., 1999) and the fact that the surface horizons, with the highest carbon content, are the site of the most intense microbial and enzyme activity (Benoit et al., 2000).

The estimated half-lives (corresponding to the disappearance of half of the applied quantity) for the parent molecules are short: for metolachlor, 10 days in a grassed strip and 23 days on bare soil (Staddon et al., 2001); for atrazin, between 14 and 121 days depending on the horizon and the soil in question (Reungsang et al., 2001); for isoproturon, from 72 days on cultivated soil to 8 days in the surface horizon of a grassed soil (Benoit et al., 1999). However, the measured disappearance of a compound is in fact also the result of partial decomposition into the degradation metabolite. Actually, complete mineralization of pesticides still takes a long time despite the favorable conditions encountered in grassed soil. For instance, with samples of grassed soil under standard conditions, complete mineralization was measured to be less than $1 \%$ for isoproturon after 44 days of incubation (Benoit et al., 2000), less than $4 \%$ for metolachlor after 46 days of incubation (Staddon et al., 2001) and less than $6 \%$ for atrazin after 84 days of incubation (Mersie et al., 1999). Besides, it must be remembered that degradation metabolites can be more stable than the parent molecule (Benoit et al., 1999, 2000; Mersie et al., 1999). For instance, atrazin degrades rapidly in the open field but its degradation products can persist in the soil for up to 9 years after its application (Stoeckel et al., 1997). So, even if it seems that degradation may rather rapidly decrease the concentrations of parent compounds infiltrated in the strip, and consequently limits the risks of accumulation and leaching, it is probably not true for degradation products. More data needs to be collected on the daughter products of the major pesticides in use to be able to analyze the specific risks of accumulation and leaching of these compounds.

\subsection{Deep percolation of the compounds}

The American guidelines relating to the development of buffer zones (USDA-NRCS, 2000) assume that the risk of deep percolation of pesticides under grassed strips is not significant. This hypothesis is based on three assumptions: (i) strongly adsorbed products have a very low leaching potential, because of the role of the strip in filtering suspended matter and the retention capacity of grassed soils; (ii) weakly adsorbed products have a high leaching potential, but it cannot be expressed on grassed strips as this type of molecule is present only at small concentration in the incoming surface runoff water due to rapid infiltration of products at the application plot level, and (iii) whenever leaching occurs, subsurface flows are less prejudicial than allowing surface runoff to directly enter the stream, due to the adsorption and degradation capacity of soil and vegetation in the buffer.

The first and third assumptions appear to be justified, even if for the first, a doubt remains about the effective retention of the finest and most contaminated solid particles (Lecomte, 1999; Mercier, 1998).

But the second is not. In fact, several studies have shown the presence of pesticides with a low $K_{o c}$ in runoff water from agricultural fields (Lennartz et al., 1997; Louchart et al., 2001; Neumann et al., 2002; Schiavon et al.; 1995; Wauchope, 1978).

Furthermore, several experimental results showed the existence of significant percolation of pesticides below grassed strips. With a strip established downstream of a maize plot treated with atrazin, for instance, the annual quantities leached below $120 \mathrm{~cm}$ under the grassed strip relative to the area of the plot were of the order of 0.6 to $2.9 \mathrm{~g} \cdot \mathrm{ha}^{-1}$ for an applied dose of $750 \mathrm{~g} \cdot \mathrm{ha}^{-1}$ (Delphin and Chapot, 2001). The maximum concentrations measured by these authors in the soil solution at a $60 \mathrm{~cm}$ depth were as high as $10 \mathrm{mg} \cdot \mathrm{L}^{-1}$ for atrazin and $6 \mathrm{mg} \cdot \mathrm{L}^{-1}$ for deethylatrazin. The authors explain that in the hydrologic conditions concerned the transfer occurred in two stages: (i) rapid transfer during the period following application of the product, but limited to the first $60 \mathrm{~cm}$ because of the evapotranspiration of both the crop and the strip, leading to a deficit water balance, and (ii) transport to a greater depth through the leaching of the adsorbed molecules after the growing period of the crop, when precipitation again exceeded evapotranspiration. In this situation, the risk of contamination concerns only molecules (parent molecules or metabolites) sufficiently persistent to still be present in the soil profile once the growing period of the crop has ended. Two studies also showed the temporary and localized contamination of a shallow water table by atrazin and alachlor beyond a buffer system, both of which are attributed to infiltration of surface runoff in a grassed strip (Lowrance et al., 1997; Vellidis et al., 2002). The peak concentration of atrazin measured in the water table was $6 \mu \mathrm{g} \cdot \mathrm{L}^{-1}$ immediately upstream of the strip and $2 \mu \mathrm{g} \cdot \mathrm{L}^{-1}$ downstream, for a runoff concentration of $90 \mu \mathrm{g} \cdot \mathrm{L}^{-1}$ (Lowrance et al., 1997). According to the authors, the very short transfer times can only be attributed to contamination by surface runoff and not to subsurface spread from the treated plot.

The occurrence of pesticide transport to depth under grassed strips may be linked both to the existence of macropore-type rapid transfer paths and to the leaching of previously adsorbed pesticides on the soil matrix. Macropores, which can explain the high infiltrability of grassed soils, constitute potential hydraulic bypasses with regard to the retention capacities of the porous matrix. Several observations suggest the existence of these structures:

(i) in situ concentration measurements using porous ceramic cups located $60 \mathrm{~cm}$ below a grassed strip, indicating contamination of the soil solution with atrazin and deethylatrazin in a time incompatible with matrix transfers (Delphin and Chapot, 2001);

(ii) particularly rapid bromide and isoproturon elution curves obtained on an undisturbed column (Benoit et al., 2000); 
(iii) in situ measurements under a grassed strip that had received contaminated runoff, showing residual concentrations on the soil matrix too small to be explained by Darcy-type matrix transport which in principle presents sufficiently long contact times and large exchange areas for higher soil matrix concentrations (Souiller et al., 2002).

However, the role of the macropores should not be overrated. Not all the macropores present in the soil are necessarily active; only those hydraulically connected to the surface contribute to the transfers, while the others remain dry through the capillary barrier effect. In addition, the macropore walls can also be the site of active adsorption, linked to the presence of organic substances (Edwards et al., 1992). The results concerning the contribution of macropores to infiltration in grassed strips are still too partial and too few to permit any quantitative conclusion about the risk of deep percolation due to these poral structures.

There are virtually no results on the leaching of products already trapped in a grassed strip. It has been shown that bound products on the surface of a grassed strip can be salted out during subsequent runoff episodes (Schmitt et al., 1999; Watanabe and Grismer, 2001). But it has generally been shown that adsorption in the soil of a grassed strip is less reversible than in bare soil and that reversibility decreases rapidly with time so that the risk would be limited (Benoit et al., 1999). With isoproturon, it has also been shown that salting out does not concern the parent product, which decomposes rapidly, but rather its metabolites, which are more stable and whose fate is intrinsically linked to the evolution of the soil organic matter to which they are tightly bound (Benoit et al., 2000).

\subsection{Subsurface lateral transport}

The occurrence of subsurface lateral transport in grassed strips must be questioned mainly in the case of riparian strips where this type of flow may directly contaminate the river. Subsurface transport is more likely when there is a discontinuity in the porous matrix (original stratification or stratification of anthropic origin, e.g. plough pan) that can lead to the formation of a rapid saturated lateral flow during the infiltration events. An example of this was identified under a riparian buffer zone established on a soil with an impermeable horizon at $1 \mathrm{~m}$ depth (Bosch et al., 1994): in the wet season, a gravitational saturated lateral flow was observed above this horizon. However, the risk of transfer was not very significant, because of the low measured velocities, around $1.4 \mathrm{~mm}$ per hour (Bosch et al., 1996). It may also be stressed that a difference in conductivity between the root mat of a grassy cover and the underlying horizon $(\times 3$ in winter, $\times 25$ in spring) is likely to favor lateral flows (Souiller et al., 2002). Actually in-situ measurements confirm that a difference does exist between the infiltration measured during runoff simulations and the theoretical infiltration deduced from direct measurements of vertical hydraulic conductivity, the theoretical value being significantly smaller than the measured value, which suggests the existence of a significant lateral flow (Souiller et al., 2002). Elsewhere, it was observed on a physical laboratory model that lateral flow representing between 4 and $7 \%$ of the rainfall takes place in the root mat $(3 \mathrm{~cm})$ of a fescue sward established on a $3 \%$ slope (Watanabe and Grismer,
2001). But the associated loss of diazinon was low $(<0.9 \%)$ due to the adsorption process (Watanabe and Grismer, 2001).

In fact, it seems that the risk of lateral subsurface transport is limited to specific situations. Shallow flows occurring within the root zone, even if significant in terms of water flow, should induce limited pesticide transport due to the strong adsorption capacity of soil and root materials. Thus, transport could occur only for "very thin" strips located along rivers, where contact time can be too short. But deeper transport can in theory be possible for a wider range of situations, since the leaching risk has been demonstrated (see Sect. 2.2) and because of a reduced adsorption capacity of the under-root zone. The groundwater flow velocity and the length of groundwater pathway between the infiltrating zone (i.e. the grassed strip) and the river will also be determining. Critical situations will be associated with coarse soils (because of their high permeability) surrounding an impermeable layer, and particularly near a river.

\subsection{Knowledge needs about pesticide fate in grassed strips}

The fate of pesticides intercepted by grassed strips should clearly be taken into account when evaluating the performance of the strips or when deciding on the installation of strips to reduce water pollution by pesticides. As reported above there is a significant number of data indicating that the intercepted pesticides are not irreversibly fixed or fully degraded in the strip. But, because most studies on grassed strips focused in priority on the filtering processes over short timescales, little is known about the significance of pesticide losses from the strip after interception. Predicting the fate of pesticides after their interception by the strip seems even more difficult than predicting the interception itself. Our review suggests two major points that should be studied more closely.

First, the study of the fate of the intercepted pesticides should not be restricted to the parent compounds but should be extended to the degradation by-products. There is a general agreement to recognize that degradation processes are rather intense in grassed strips due to their high microbiological activity, but the available data essentially concerns the parent compounds, and only few data were acquired on the degradation rate of the daughter compounds, which, as already noted, may also be a source of water contamination.

Second, subsurface flow processes, whether of preferential type or not, remain largely unknown. This is in fact a general problem in the study of subsurface hydrological processes since in most soils the poral structure and the active water pathways below the soil surface can rarely be identified and observed. But it is even more a problem in grassed strips for two reasons. One is that soils of grassed strips exhibit most often a larger macroporosity than usual agricultural soils since they are subject to larger faunal and rooting activity over long terms. This implies that the possibility of preferential flow is certainly greater in grassed strips than elsewhere. Another reason is that many grassed strips are located at the bottom of slopes and close to rivers, which correspond to wet situations that enhance the possibility of significant subsurface flow. 


\section{NUMERICAL MODELING OF THE FUNCTIONING OF GRASSED STRIPS}

Mechanistic numerical models have been produced to integrate the different processes described above, with the aim of explaining experimentally measured outflows of water and pollutants from grassed strips of given dimensions and subject to a given incoming runoff. These tools represent each process by mathematical equations. The parameters involved in these equations usually have a physical sense and can therefore be measured either directly or indirectly. We review hereafter the main modeling approaches that have been published so far to our knowledge.

The VFSMOD (Muñoz-Carpena et al., 1999) and TRAVA (Deletic, 2001) are field-scale, storm-based models designed to route an incoming hydrograph and sedimentograph from an adjacent field through a grassed strip and calculate the outflow, infiltration and sediment trapping efficiency. They represent surface flow by means of the kinematic wave equation solved in 1D and allow a fine discretization of the grassed strip characteristics (vegetation roughness and density, slope and soil permeability). Infiltration is calculated using the Green and Ampt equation. A distinguishing feature of these models is their specific representations of solid particle transfers: physicallybased equations established at the University of Kentucky and the University of Aberdeen, respectively, derived from laboratory experiments. They have been successfully tested on experimental data: VFSMOD was calibrated and validated on natural (Muñoz-Carpena et al., 1999) and simulated (Abu-Zreig et al., 2001) rainfall events, while TRAVA was successfully calibrated on runoff simulations (Deletic, 2000). But unfortunately, these models do not represent solute transport and adsorption-desorption processes.

The CREAMS model, initially developed to work on the plot scale and over long periods, has also been used to model the impact of a grassed strip on surface runoff and particle transfer (Flanagan et al., 1989). Like the previous two models it resolves the kinematic wave equation in 1D and the Green and Ampt equation. The model has been tested on natural events, but with variable results: it has been shown that even though it reproduces more or less accurately daily runoff volumes, the occurrence of runoff events and seasonal losses of sediment, there is no correlation between simulated and measured values for sediment losses per event (Cooper et al., 1992).

Another published model is the GRAPH model (Lee et al., 1989), which can be used to simulate solute transport, more particularly phosphorus transport, through a grassed strip in association with a runoff and erosion model. It takes into account the processes of advection, infiltration, biological sink terms and adsorption/desorption on soil and suspended matter. GRAPH was validated on phosphorus transfer data from open field experiments.

Last is the Riparian Ecosystem Management Model (REMM) (Lowrance et al., 2000). This model takes into account a large number of processes, and particularly subsurface lateral flow, that is not taken into account by previous models, to estimate water, nitrogen, phosphorus and sediment transfer through a buffer system. Flow is calculated on a daily time step, which involves a number of simplifications, particularly for simulating surface runoff: the latter is represented by the ratio between an empirical concentration time and the duration of the event. Moreover, the model does not allow a fine spatial discretization: only nine macro-compartments are described, with three distinct soil layers and three vegetation zones. It follows that the validation of REMM is still partial. Even though the modeling of water table heights is generally acceptable, the error on runoff volumes is far higher (Inamdar et al., 1999; Tucker et al., 2000).

Finally, it is important to underline that none of these models tackles the question of pesticide transport across a grassed strip. In their present state of development, the existing models only simulate the transfer of water and suspended matter. The chemical elements that are considered in these models are, so far, phosphorus and nitrogen. Moreover, the concepts used in these models fail to recognize the true complexity of the hydrodynamic processes occurring in a strip. For instance, the Green and Ampt equation, widely used to represent infiltration, is fairly restrictive: it assumes homogeneous initial soil water content, one-dimensional flow, and ignores the phenomenon of sorptivity. In particular, it fails to take account of infiltration in a stratified soil or in the presence of a water table. Also, no reported model considers subsurface flows explicitly, which in fact would require a 2D modeling approach.

\section{RECOMMENDATIONS FOR THE INSTALLATION OF GRASSED STRIPS}

The complexity and variability of the factors controlling the effectiveness of a grassed strip are so great that no satisfactory quantitative tool is presently available to define the optimum characteristics of a strip in a particular hydrologic situation, either on the strip scale, as explained in the previous part, or on the catchment scale. The current recommendations for the introduction of this type of system (siting and sizing) are essentially qualitative or the result of empirical approaches. This section reports the existing approaches.

\subsection{Locating grassed systems in a watershed}

Two reports, one written in France (Comité d'Orientation pour la Réduction de la Pollution des Eaux par les Nitrates, les phosphates et les produits phytosanitaires provenant des activités agricoles (CORPEN), 1997) and the other in the United States of America (USDA-NRCS, 2000), present current practices relating to the development of grassed strips. Although the reasoning differs on some points, the guidelines are very similar:

(i) A first very obvious guideline is that grassed systems should be sited to intercept runoff from cultivated plots.

(ii) A second defines the upstream to downstream management of the catchment. It is based on the fact that surface runoff, initially diffuse at the level of the plot where it appears, becomes more concentrated as it flows down the watershed in rills, gullies and channels, leaving an ever-greater mark on the landscape until cropping is no longer possible. Different systems are required to match these different types of flow (different in velocity, particle load and height): in-field or edge-offield grassed strips to intercept diffuse runoff; the grassing of 


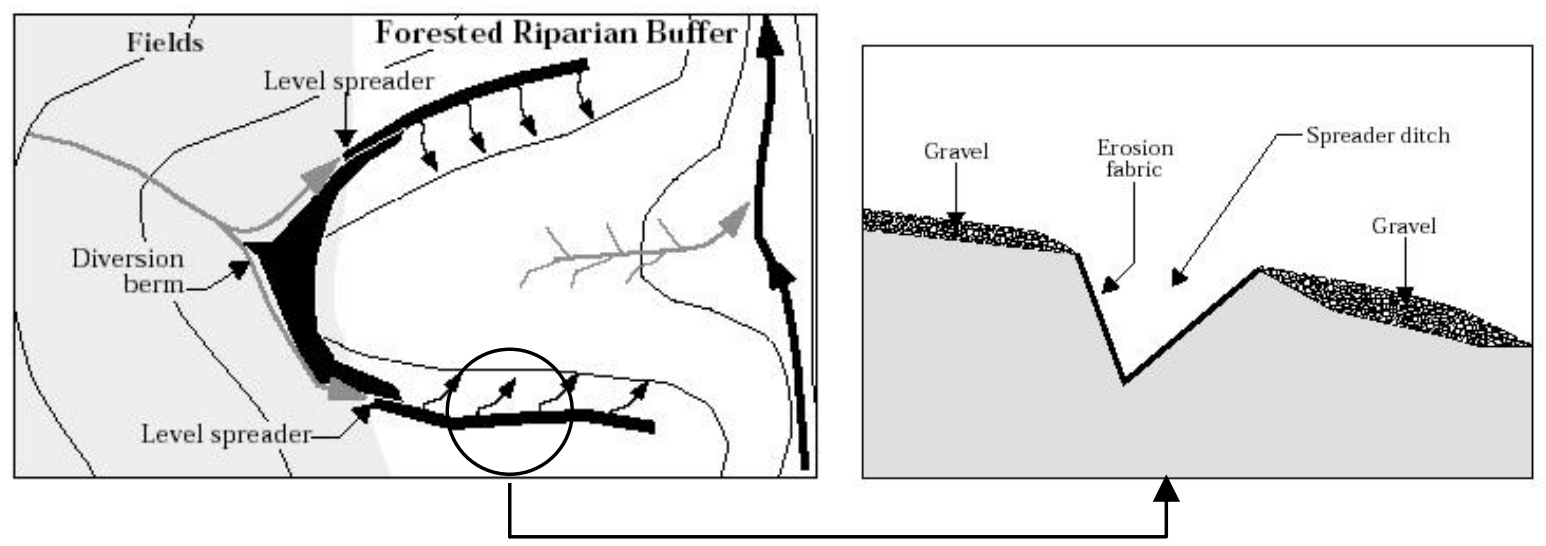

Figure 3. Embankment proposed in the United States to break and disperse flow before entering the strip (USDA-NRCS, 2000).

existing thalwegs or the development of grassed thalwegs to control concentrated runoff; the grassing of stream banks to intercept flows before they enter the water resource to be protected. Moreover, American guidelines take account of the fact that runoff concentration can also limit the effectiveness of buffer systems. They therefore recommend that buffer zones be located as close as possible to the source, advocating the use of in-field grassed strips parallel to the contour lines. With edge-of field strips there is a larger risk of concentrated flows because of sediment deposits. The downstream development of riparian strips needs to take this factor into account and provide for dispersion of the flow before it enters the strips. This can be done when the strip is installed, either by smoothing the terrain or by developing the buffer system to match contour lines, or via a purpose-built system. An embankment to break the flow arriving from upstream, associated with small ditches that can overflow uniformly onto the strip, can play this role (see Fig. 3).

(iii) The third guideline concerns only riparian strips. American authors have shown that most of the runoff water in a river comes from small streams in the upper parts of the watershed, temporary or level 1 or 2 streams. This category of stream is therefore the one that must be protected first and foremost. Protection by riparian strips of higher level (level 3 or 4) branches of the hydrographic network can have only a very limited effect on stream quality as the area with direct runoff to this zone will be negligible on a watershed scale.

Until now, no experimental data has been published about the validity of such locating recommendations. Nevertheless, a distributed hydrological modeling work (Lecomte, 1999) confirms the fact that a small grassed fraction of the catchment area can significantly reduce contaminant fluxes at the outlet if the grassed strips are located on contributive waterways and at the low end of contributive plots. We also underline that existing recommendations do not take account of the subsurface processes. As stressed above, this is particularly problematic in the case of riparian strips which are close to rivers and where groundwater often comes up to the surface.

\subsection{Sizing of the strip}

Although the effectiveness of grassed strips in dissipating pollutant flows has been demonstrated by numerous authors, there are few references describing the dimensions that these systems should be given for optimum effectiveness according to the particular features of the site.

In France (Comité d'Orientation pour la Réduction de la Pollution des Eaux par les Nitrates les phosphates et les produits phytosanitaires provenant des activités agricoles (CORPEN), 1997), there are no bibliographical references and only a few qualitative rules on sizing have been formulated, primarily based on the distinction between diffuse flow and concentrated flow. Quantified values based on experimental results obtained at the Arvalis site of La Jaillière in the Loire Atlantique (Patty, 1997) are provided by way of information. For diffuse runoff, strip lengths of 10 and $20 \mathrm{~m}$ are proposed for hillslopes of under and over $100 \mathrm{~m}$, respectively; if the flow is not perpendicular to the field edges, the lengths must be estimated in the direction of the flows. For concentrated runoff, the entire flow channel should be grassed or meadows created "in steps" if the rainfall area is greater than about 100 hectares (see Fig. 4).

American technical guidelines do not include any quantitative rules for sizing, either (USDA-NRCS, 2000). Nevertheless, it is noted that sizing should be based on the protection objectives (a strip to stop solid particles will be smaller than one to intercept soluble products such as nitrates and pesticides), the site-specific conditions (the strip will be larger if the soil permeability is low, the soil is close to saturation, particularly in the presence of a surface water table, and the runoff area is large) and, lastly, on what is economically or even politically feasible. Despite this "mechanistic reasoning", a "standard length" is proposed: 50 feet $(15 \mathrm{~m})$ for a stated $50 \%$ effectiveness if the runoff is diffuse and modulo the previously mentioned parameters. As far as sediment transfer is concerned, classes of grassed strip size have been established empirically, using an externally calibrated erosion coefficient.

Obviously, such fixed recommended strip lengths are contradictory to the multiplicity of processes and variables affecting 


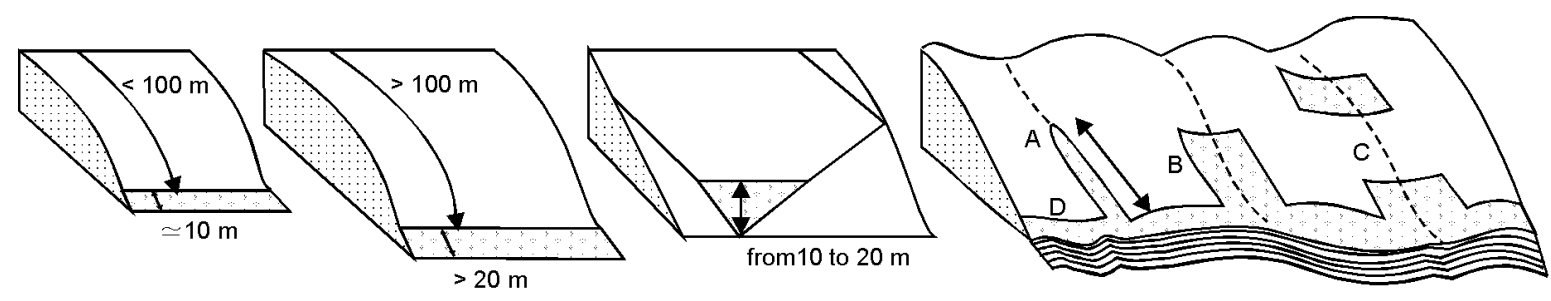

1. Short side

Sizing of grassed bufferzones (CORPEN 1997)
2. Long side 3. Runoff concentration
in a corner of the field
4. Association of a riparian strip and buffers located on concentrated flows

A: grassed waterways

B : meadow

C : meadows in "cascade"

$\mathrm{D}$ : variable width (for a straight field edge)

Figure 4. Typical management schemes proposed in France by the Orientation Committee for Environmentally-friendly Agricultural Practices considering the Environment (Comité d'Orientation pour la Réduction de la Pollution des Eaux par les Nitrates les phosphates et les produits phytosanitaires provenant des activités agricoles (CORPEN), 1997).

the retention capacity of a grassed strip both in space and time (as explained in the first part). Such lengths are probably satisfactory on average but they should be optimized for specific situations, which certainly require more mechanistic approaches.

Other approaches rely on empirical formulas that consider only single acting processes and compute the expected flow reduction in a grassed strip of a given size. These formulas have been established with regard to the retention of solid particles (Flanagan et al., 1985; van Dijk et al., 1996), nitrogen and phosphorus (Lim et al., 1998), or to the limitation of surface runoff (Mander et al., 1997). Their applicability is severely limited through the use of empirical coefficients without physical significance and calibrated under particular conditions. Moreover, by construction they are unable to take account of several interacting processes in a dynamic way.

Two physically-based approaches to the sizing of grassed strips can also be found in the literature. The first (Suwandono et al., 1999) uses a front-end model based on a combination of the NRCS curve number method, the unit hydrograph and the modified Universal Soil Loss Equation (based on vegetation, soil type and topography) to generate a rainfall hyetograph, a runoff hydrograph and a sediment loss from the cultivated area. The VFSMOD model (Muñoz-Carpena et al., 1999), already described, is then used to test the impact of different grassing scenarios on the contaminated flow. The second is an original approach developed for permeable soils, that is based on the criterion of minimizing the impact on the alluvial aquifer of flows infiltrating the buffer zone (Lin et al., 2002). A probable depth of pesticide spread in the soil is calculated mechanistically, with the convection-dispersion relationship solved for a 1D permanent flow. Knowing the topography of the hillslope, the buffer zone is sized so that the upstream boundary of the buffer zone receiving the contaminated runoff is higher than the level established by the minimum distance to be observed between the water table and the soil surface to avoid contamination.

Finally, the ideal sizing strategy should combine physicallybased descriptions of surface and subsurface flows, the latter being bi-dimensional to take both vertical and lateral flows into account. But new numerical models have to be developed first as the existing models described above are not satisfactory (see Sect. 3).

\section{CONCLUSION}

Experimental studies to date have identified the processes and factors determining the effectiveness of a grassed strip to intercept pesticides. Nevertheless, this review highlighted some major processes that are of importance in the functioning of grassed strips and for which insufficient data and observations are presently available: the channeling of surface flow inside the grassed strips, the sedimentation and infiltration of highly concentrated fine solid particles, the adsorption of chemicals on soil and plants related to their kinetic aspects and the characterization of organic matters, and the temporal evolution of strip physico-chemical characteristics. Further research is required on the effectiveness of grass strips under natural conditions, but primarily on systems for which boundary conditions, initial conditions, and intrinsic physico-chemical properties are measured.

The question was then raised of what the intercepted products become, in the short and long terms. Our review suggests two major points that should be studied in the future. The first is the fate of degradation metabolites, as they were found to be more stable than the parent molecules. The second is the impact of subsurface flows, of preferential type or not, on the global effectiveness of a buffer system, particularly in the case of riparian strips.

In the present situation, there is considerable uncertainty about the development of grassed systems in order to stop both surface- and groundwater contamination by pesticides. Technical guidelines for the siting and sizing of these developments are still essentially qualitative and based on results obtained on a few particular sites. The literature to date still does not allow quantitative rules to be formulated, so the prediction capacities need to be improved. This is not only an environmental issue but also an economic one, as creating and maintaining a buffer 
zone costs money. Quantitative information on the expected effectiveness of the installation of a grassed strip in terms of flow reduction and of impact on the quality of aquatic environments would be useful for managers of rural areas, but it would also be useful to convince a greater number of farmers to give up part of their cropping area for installing strips.

Improving the prediction tools involves taking the particular features of each site into account, and this requires the use of physically-based numerical models capable of integrating the different processes that determine the dissipation capacity of grassed strips. Mechanistic models have already been proposed but these require further development, in particular by integrating the whole range of transport processes and chemical reactions affecting pesticides on the surface and subsurface flows.

With the development of a prediction tool on the scale of the grassed strip, the formulation of short-term recommendations could be envisaged for a wide range of standard situations, through the testing of development scenarios. But such a tool would then need to be integrated into a more general management approach on the hillslope or the watershed scale and allow greater account to be taken both of the initial situation and of the upstream conditions.

Acknowledgments: The authors thank the following for their financial support: the Directorate for Economic Studies and Environmental Assessment of the French Ministry of the Environment and Sustainable Development ("Assessment and reduction of the risks associated with pesticide use" program), the General Directorate for Forestry and Rural Affairs (formerly the DERF) of the French Ministry of Agriculture, Food, Fisheries and Rura Affairs, and CEMAGREF and INRA through the AQUAE Joint Research Program. They also thank Garth Evans for the English translation.

\section{REFERENCES}

Abu-Zreig M., Rudra R.P., Whiteley H.R. (2001) Validation of a vegetated filter strip model (VFSMOD), Hydrol. Process. 15, 729-742.

Arora K., Mickelson S.K., Baker J.L., Tierney D.P., Peters C.J. (1996) Herbicide retention by vegetative buffer strips from runoff under natural rainfall, Trans. ASAE 39, 2155-2162.

Asmussen L.E., White A.W., Hauser E.W., Sheridan J.M. (1977) Reduction of 2,4D load in surface runoff down a grassed waterway, J. Environ. Qual. 6, 159-162.

Benoit P., Barriuso E., Vidon P., Réal B. (1999) Isoproturon sorption and degradation in a soil from grassed buffer strip, J. Environ. Qual. 28, $1-9$.

Benoit P., Barriuso E., Vidon P., Réal B. (2000) Isoproturon movement and dissipation in undisturbed soil cores from a grassed buffer strip, Agronomie 20, 297-307.

Beven K., Germann P. (1982) Macropores and water flow in soils, Water Resour. Res. 18, 1311-1325.

Bosch D.D., Hubbard R.K., West L.T., Lowrance R.R. (1994) Subsurface flow patterns in a riparian buffer system, Trans. ASAE 37, 17831790.

Bosch D.D., Sheridan J.M., Lowrance R. (1996) Hydraulic gradients and flow rates of a shallow coastal plain aquifer in a forested riparian buffer, Trans. ASAE 39, 865-871.

Calvet R., Tercé M., Arvieu J.C. (1980) Adsorption des pesticides par les sols et leur constituants. III. Caractéristiques générales de l'adsorption des pesticides, Ann. Agron. 31, 239-257.

C.A.Vaucluse, Efficacité des bandes enherbées sur la qualité des eaux de ruissellement., Groupement de développement agricole-Viticulture de Vaucluse, 2000, 26 p.
Comité d'Orientation pour la Réduction de la Pollution des Eaux par les Nitrates les phosphates et les produits phytosanitaires provenant des activités agricoles (CORPEN), Produits phytosanitaires et bandes enherbées, MAP - MATE, 1997, 88 p.

Cooper A.B., Smith C.M., Bottcher A.B. (1992) Predicting runoff of water, sediment, and nutrients from a New-Zealand grazed pasture, Trans. ASAE 35, 105-112.

Dabney S.M., Meyer L.D., Harmon W.C., Alonso C.V., Foster G.R. (1995) Depositional patterns of sediment trapped by grass hedges, Trans. ASAE 38, 1719-1729.

Deletic A. (2000) Sediment behaviour in overland flow over grassed areas., Ph.D. thesis, University of Aberdeen, 175 p.

Deletic A. (2001) Modelling of water and sediment transport over grassed areas, J. Hydrol. 248, 168-182.

Delphin J.E., Chapot J.Y. (2001) Leaching of atrazine and deethylatrazine under a vegetative filter strip, Agronomie 21, 461-470.

Dillaha T.A., Reneau R.B., Mostaghimi S., Lee D. (1989) Vegetative filter strips for agricultural nonpoint source pollution control, Am. Soc. Agr. Eng. 32, 513-519.

Dosskey M.G. (2001) Toward quantifying water pollution abatement in response to installing buffers on crop land, Environ. Manage. 28, 577-598.

Dosskey M.G. (2002) Setting priorities for research on pollution reduction functions of agricultural buffers, Environ. Manage. 30, 641650.

Edwards D.R., Shipitalo M.J., Traina S.J., Edwards C.A., Owens L.B. (1992) Role of Lumbricus Terrestris (L.) burrows on quality of infiltrating water, Soil Biol. Biochem. 24, 1555-1561.

Flanagan D.C., Neibling W.H., Foster G.R., Burt J.P., Applicability of CREAMS in filter strip design, National Soil Erosion Research Laboratory, USDA-ARS, 1985, 22 p.

Flanagan D.C., Foster G.R., Neibling W.H., Burt J.P. (1989) Simplified equations for filter strip design, Trans. ASAE 32, 2001-2007.

Ghadiri H., Rose C.W., Hogarth W.L. (2001) The influence of grass and porous barrier strips on runoff hydrology and sediment transport, Trans. ASAE 44, 259-268.

Gril J.J., Badel E., Patty L., Dutertre A., Mocquet M. (1996) Mise au point d'une méthode d'évaluation : la simulation de ruissellement avec utilisation d'un traceur coloré, Rapport interne, 15 p.

Inamdar S.P., Sheridan J.M., Williams R.G., Bosch D.D., Lowrance R., Altier L.S., Thomas D.L. (1999) Riparian Ecosystem Management Model: I. Testing of the hydrologic component for a coastal plain riparian system, Trans. ASAE 42, 1679-1689.

Jin C.-X., Römkens M.J.M., Griffioen F. (2000) Estimating manning's roughness coefficient for shallow overland flow in non-submerged vegetative filter strips, Trans. ASAE 43, 1459-1466.

Krutz L.J., Senseman S.A., Dozier M.C., Hoffman D.W., Tierney D.P. (2003) Infiltration and adsorption of dissolved atrazine and atrazine metabolites in buffalograss filter strips, J. Environ. Qual. 32, 2319_ 2324.

Lecomte V. (1999) Transfert de produits phytosanitaires par le ruissellement et l'érosion de la parcelle au bassin versant, $\mathrm{Ph}$. D. thesis, Paris, France, 210 p.

Lee D., Dillaha T.A., Sherrard J.H. (1989) Modeling phosphorus transport in grass buffer strips, J. Environ. Eng. 115, 409-427.

Lee K.-H., Isenhart T.M., Schultz R.C., Mickelson S.K. (2000) Multispecies riparian buffers trap sediment and nutrients during rainfall simulations, J. Environ. Qual. 29, 1200-1205.

Lennartz B., Louchart X., Voltz M., Andrieux P. (1997) Diuron and Simazine losses to runoff water in mediterranean vineyards, J. Environ. Qual. 26, 1493-1502.

Lickfeldt D.W., Branham B.E. (1995) Sorption of nonionic compounds by kentucky bluegrass leaves and thatch., J. Environ. Qual. 24, 980985.

Lim T.T., Edwards D.R., Workman S.R., Larson B.T., Dunn L. (1998) Vegetated filter strip removal of cattle manure constituents in runoff, Trans. ASAE 41, 1375-1381. 
Lin C.Y., Chou W.C., Lin W.T. (2002) Modeling the width and placement of riparian vegetated buffer strips: a case study on the Chi-Jia-Wang Stream (Taiwan), J. Environ. Manage. 66, 269-280.

Louchart X., Voltz M., Andrieux P., Moussat R. (2001) Herbicide transport to surface waters at field and watershed scales in a mediterranean vineyard area, J. Environ. Qual. 30, 982-991.

Lowrance R., Vellidis G., Wauchope R.D., Gay P., Bosch D.D. (1997) Herbicide transport in a managed riparian forest buffer system, Trans. ASAE 40, 1047-1057.

Lowrance R., Altier L.S., Williams R.G., Inamdar S.P., Sheridan J.M., Bosch D.D., Hubbard R.K., Thomas D.L. (2000) REMM: the Riparian Ecosystem Management Model, J. Soil Water Conserv. 27-34.

Madrigal I., Benoit P., Barriuso E., Etiévant V., Souiller C., Réal B., Dutertre A. (2002) Capacité de stockage et d'épuration des sols de dispositifs enherbés vis-à-vis des produits phytosanitaires, Étude Gestion Sols 9, 287-302.

Mander Ü., Kuusemets V., Lohmus K., Mauring T. (1997) Efficiency and dimensioning of riparian buffer zones in agricultural catchments, Ecol. Eng. 8, 299-324.

Margoum C., Gouy C., Madrigal I., Benoit P., Smith J., Johnson A.C., Williams R.J., Sorption properties of isoproturon and diflufenican on ditch bed sediments and organic matter rich materials from ditches, grassed strip and forest soils, BCPC Symposium, 2001.

Mercier P. (1998) Contribution méthodologique à l'étude des matières en suspension. Application au transfert particulaire en sol drainé. Ph.D. thesis, INRA Versailles, $164 \mathrm{p}$.

Mersie W., Seybold C., Tsegaye T. (1999) Movement, adsorption and mineralization of atrazine in two soils with and without switchgrass (Panicum virgatum) roots, Eur. J. Soil Sci. 50, 343-349.

Meyer L.D., Dabney S.M., Harmon W.C. (1995) Sediment-trapping effectiveness of stiff-grass hedges, Trans. ASAE 38, 809-815.

Misra A.K., Baker J.L., Mickelson S.K., Shang H., Effectiveness of vegetative buffer strips in reducing herbicide transport with surface runoff under simulated rainfall, Mid-central meeting of the ASAE, 1994.

Misra A.K., Baker J.L., Mickelson S.K., Shang H. (1996) Contributing area and concentration effect on herbicide removal by vegetative buffer strips, Trans. ASAE 39, 2105-2111.

Muñoz-Carpena R., Parsons J.E., Gilliam J.W. (1999) Modeling hydrology and sediment transport in vegetative filter strips, J. Hydrol. 214 $111-129$.

Muscutt A.D., Harris G.L., Bailey S.W., Davies D.B. (1993) Buffer zones to improve water quality: a review of their potential use in UK agriculture, Agr. Ecosys. Environ. 45, 59-77.

Neumann M., Schultz R., Shäfer K., Müller W., Mannheller W., Liess M. (2002) The significance of entry routes as point and non-point sources of pesticides in small streams, Water Res. 36, 835-842.

Norris V. (1993) The use of buffer zones to protect water quality: a review, Water Resour. Manage. 7, 257-272.

Patty L. (1997) Limitation du transfert par ruissellement vers les eaux superficielles de deux herbicides (isoproturon et diflufénicanil). Méthodologie analytique et étude de l'efficacité de bandes enherbées, Ph.D. thesis, Grenoble I, 217 p.

Patty L., Real B., Gril J.J. (1997) The use of grassed buffer strips to remove pesticides, nitrate and soluble phosphorus compounds from runoff water, Pestic. Sci. 49, 243-251.

Pot V., Benoit P., Yra A., Martinez Cordon M.-J., Labat C., Dissipation of isoproturon and metribuzin herbicides in undisturbed grassed buffer strip soil columns, Congrès du Groupe Français des pesticides, Aix en Provence, 2003, 4 p.

Rankins A.J., Shaw D.R., Boyette M. (2001) Perennial grass filter strips for reducing herbicide losses in runoff, Weed Sci. 49, 647-651.

Reungsang A., Moorman T.B., Kanwar R.S. (2001) Transport and fate of atrazine in midwestern riparian buffer strips, J. Am. Water Ressour. Assoc. 37, 1681-1692.

Rohde W.A., Asmussen L.E., Hauser E.W., Wauchope R.D., Allison H.D. (1980) Trifluralin movement in runoff from a small agricultural watershed, J. Environ. Qual. 9, 37-42.

Schiavon M., Perrin-Ganier C., Portal J.M. (1995) La pollution de l'eau par les produits phytosanitaires : état et origine, Agronomie 15, $157-170$.

Schmitt T.J., Dosskey M.G., Hoagland K.D. (1999) Filter strip performance and processes for different vegetation, widths, and contaminants, J. Environ. Qual. 28, 1479-1489.

Smith R. (2002) Infiltration theory for hydrologic applications, A.g. Union, Washington, 2002.

Souiller C., Coquet Y., Pot V., Benoit P., Réal B., Margoum C., Laillet B., Labat C., Vachier P., Dutertre A. (2002) Capacités de stockage et d'épuration des sol de dispositifs enherbés vis-à-vis des produits phytosanitaires, Étude Gestion Sols 9, 269-285.

Spatz R., Walker F., Hurle K. (1997) Effect of grass buffer strips on pesticide runoff under simulated rainfall, Med. Fac. Landbouww. Univ. Gent. 62, 799-806.

Srivastava P., Edwards D.R., Daniel P.A., Moore P.A., Costello T.A. (1996) Performance of vegetative filter strips with varying pollutant source and filter strip lengths, Trans. ASAE 39, 2231-2239.

Staddon W.J., Locke M.A., Zablotowicz R.M. (2001) Microbiological characteristics of a vegetative buffer strip soil and degradation and sorption of metolachlor, Soil Sci. Soc. Am. J. 65, 1136-1142.

Stoeckel D.M., Mudd E.C., Entry J.A. (1997) Degradation of persistent herbicides in riparian wetlands, in: Phytoremediation of soil and water contaminants, A.C. Society (Eds.), pp. 114-132.

Suwandono L., Parsons J.E., Munoz-Carpena R., Design guide for vegetative filter strips using VFSMOD, 1999 ASAE/CSAE-SCGR Annual International Meeting, Toronto, Ontario, Canada, 1999, pp. 1-7.

Tingle C.H., Shaw D.R., Boyette M., Murphy G.P. (1998) Metolachlor and metribuzin losses in runoff as affected by width of vegetative filter strips, Weed Sci. 46, 475-479.

Tisdall J.M., Oades J.M. (1982) Organic matter and water-stable aggregates in soils, J. Soil Sci. 33, 141-163.

Tucker M.A., Thomas D.L., Bosch D.D, Vellidis G. (2000) GIS-based coupling of GLEAMS end REMM hydrology: II. Field test results, Trans. ASAE 43, 1535-1544.

USDA-NRCS, Conservation buffers to reduce pesticide losses, USEPA, Washington, 2000, $21 \mathrm{p}$.

van Dijk P.M., Kwaad F.J.P.M., Klapwijk M. (1996) Retention of water and sediment by grass strips, Hydrol. Process. 10, 1069-1080.

Vellidis G., Lowrance R., Gay P., Wauchope R.D. (2002) Herbicide transport in a restored riparian forest buffer system, Trans. ASAE 45, 89-97.

Watanabe H., Grismer M.E. (2001) Diazinon transport through inter-row vegetative filter strips: micro-ecosystem modeling, J. Hydrol. 247, 183-199.

Wauchope R.D. (1978) The pesticide content of surface water draining from agricultural fields-a review, J. Environ. Qual. 7, 459-472. 